Meta

Journal des traducteurs

Translators' Journal

\title{
Conference Interpreting: Quality in the Ears of the User
}

\section{Ingrid Kurz}

Volume 46, numéro 2, juin 2001

Évaluation : paramètres, méthodes, aspects pédagogiques /

Evaluation: Parameters, Methods, Pedagogical Aspects

URI : https://id.erudit.org/iderudit/003364ar

DOI : https://doi.org/10.7202/003364ar

Aller au sommaire du numéro

Éditeur(s)

Les Presses de l'Université de Montréal

ISSN

0026-0452 (imprimé)

1492-1421 (numérique)

Découvrir la revue

Citer cet article

Kurz, I. (2001). Conference Interpreting: Quality in the Ears of the User. Meta, 46(2), 394-409. https://doi.org/10.7202/003364ar

\section{Résumé de l'article}

Que veut dire un auditeur qui qualifie une interprétation de "remarquable »? Quelles sont les caractéristiques qu'il juge indispensables et qu'est-ce qui l'irrite ? Après un bref résumé des études consacrées aux attentes des auditeurs, l'auteur formule l'hypothèse que l'auditoire cible est une variable essentielle dans l'équation de l'interprétation. La qualité des services d'interprétation est évaluée en termes de comparaison entre service fourni et service attendu. Par conséquent, tout système valable d'évaluation de la qualité de l'interprétation doit impérativement inclure parmi ses variables les expectations de l'utilisateur. 


\title{
Conference Interpreting: Quality in the Ears of the User
}

\author{
INGRID KURZ \\ University of Vienna, Vienna, Austria
}

\begin{abstract}
RÉSUMÉ
Que veut dire un auditeur qui qualifie une interprétation de «remarquable»? Quelles sont les caractéristiques qu'il juge indispensables et qu'est-ce qui l'irrite? Après un bref résumé des études consacrées aux attentes des auditeurs, l'auteur formule l'hypothèse que l'auditoire cible est une variable essentielle dans l'équation de l'interprétation. La qualité des services d'interprétation est évaluée en termes de comparaison entre service fourni et service attendu. Par conséquent, tout système valable d'évaluation de la qualité de l'interprétation doit impérativement inclure parmi ses variables les expectations de l'utilisateur.
\end{abstract}

\begin{abstract}
What do the recipients of interpretation mean by "good interpretation"? What are the features they consider most important and what do they find irritating? Following a brief overview of user expectation surveys, the paper contends that the target audience is an essential variable in the interpretation equation. Quality of interpretation services is evaluated by users in terms of what they actually receive in relation to what they expected. Consequently, measurements of service quality that do not include user expectations miss the point.
\end{abstract}

\section{MOTS-CLÉS/KEYWORDS}

conference interpreting, simultaneous interpreting, interpreting quality/assessment, target audience, user expectations

\section{INTRODUCTION}

"Quality must begin with customer needs and end with customer perception." (Kotler and Armstrong 1994: 568) There is no reason why this generally accepted marketing principle should not apply to conference interpreting as well.

Research into audience expectations and preferences with special regard to the definition and evaluation of interpretation quality is of crucial importance for a profession whose raison d'etre is to establish effective communication between speaker and audience. Checking our own assumptions against our listeners' feedback may provide useful orientation for practitioners, teachers and aspirant interpreters (Marrone 1993: 35).

Obviously, users want "good" interpretation, but what do the mean by good interpretation? Do they all want the same thing? What are the features they consider the most important? Can we strengthen our position in negotiations with employers, improve training, communicate more easily with the users of our services by having a better knowledge of what the consumer wants? (Mackintosh 1994: 13)

At a time of benchmarking, best practice sharing, process optimization and Total Quality Management (TQM), interpreters as comprehensive service providers must 
clearly be interested in performance enhancement and in identifying key performance indicators.

An analysis of user expectation profiles coupled with a gap analysis should help us enhance user benefits.

\section{USER-ORIENTED PROFESSIONAL STANDARDS}

Like any other professional association, AIIC (the International Association of Conference Interpreters), sees quality of service and professional standards as one of its major objectives. It has stringent criteria for the admission of new members to ensure quality now and in the future. Déjean le Féal (1990: 155) summarizes these objectives as follows: "What our listeners receive through their earphones should produce the same effect on them as the original speech does on the speaker's audience. It should have the same cognitive content and be presented with equal clarity and precision in the same type of language."

In fact, conference interpreters have emphasized the significant role played by listeners and situational factors from the very beginning as witnessed by the following selection of quotations.

According to Herbert (1952: $82 \mathrm{f}$.), it is quite clear that in a diplomatic conference the greatest attention should be paid to all the nuances of words, while in a gathering of scholars, technical accuracy will have greater importance; in a literary and artistic gathering, elegance of speech; and in a political assembly, forcefulness of expression. Similarly, the style and tone cannot be the same in a small group of three or four sitting around a table, in a committee room with a membership of twenty or fifty, and at a large public meeting where many thousands are gathered.

Gold (1973: 155) stresses the need to target the language to the expectations of the audience: interpreters should try to use the same variety of a language as the participants do. At the United Nations, e.g., some interpreters are finding that they are interpreting more and more for fewer and fewer delegates and they can thus adjust their language accordingly.

Seleskovitch (1986: 236) points out that interpretation should always be judged from the perspective of the listener and never as an end in itself: "The chain of communication does not end in the booth."

This opinion is shared by Chernov (1985), a representative of the Soviet school, who maintains that the knowledge of the situational context of the communication being interpreted is critically important.

Thiéry (1990: 42) also stresses the significance of situationality. The interpreter must always consider who is talking to whom, to what purpose, and with what possible effect. Situation analysis helps the interpreter render a better performance: "[...] when we take the trouble to look at the situation, we find ourselves in a better position to act efficiently."

In a recent publication on the Internet, Kahane (2000) observes that different listeners in the same situation may have different expectations. 


\section{RESEARCH INTEREST IN USER EXPECTATIONS}

Given the user-orientedness of the conference interpreting profession, it is somewhat surprising that studies involving users and their quality expectations have been a subject of interpretation research for only slightly more than a decade.

Stenzl (1983: 31) was one of the first authors to point out that, with the exception of Gerver's study (1972) on users' retention of consecutive and simultaneous interpretation, the research community had failed to consider user needs and expectations and that, therefore, we have only anecdotal and impressionistic indications on what conference delegates expect from interpreters and how satisfied they are with the service they receive.

Even though it was recognized that very often a good interpreter is two quite different people, being one thing to a conference participant and another to a colleague (Cartellieri 1983: 213), the first empirical study trying to elucidate criteria for the quality of interpretation (Bühler 1986) was carried out on a sample of conference interpreters rather than users.

Describing different types of multilingual events (big scientific and technical congresses, seminars, working sessions and plenary meetings of international organizations, parliamentary debates, media events, press conferences, dinner speeches, etc.) which are likely to involve different user expectations and requirements, Gile (1989: 25) concluded that the needs and expectations of the users of interpretation are not necessarily the same as the definition interpreters themselves give of their activity.

At about the same time Snelling (1989: 142) also pointed out that a target text must be targeted upon a specific audience and that it is, therefore, necessary to involve, in the interpretation equation, the audience and the specific quality of that audience. He advocated a typology of beneficiaries since knowledge and awareness of the specific requirements of the specific target group will influence the interpreter in his choice of technique and, above all, in his choice of language.

Since 1989, about a dozen researchers (Kurz 1989, 1993, 1994, 1996; Gile 1990; Meak 1990; Ng 1992; Marrone 1993; Vuorikoski 1993, 1998; Kopczynski 1994; Mack and Cattaruzza 1995; Moser1995, 1996; Collados Aís 1998; Andres 2000) have embarked upon the study of user expectations and/or responses. A number of empirical studies were carried out to establish the relative weight of factors considered relevant to quality judgements in simultaneous interpreting.

Five years after the first empirical study asking the users of interpreting services about their expectations (Kurz 1989), Pöchhacker (1994: 233) noted that the quality of the services rendered by professional interpreters was among the prime concerns of the international conference interpreting community.

Researchers' heightened interest in the quality of interpreting was also reflected in the program of the Conference on Interpretation Reasearch held in Turku, Finland, from 25-28 August 1994. It included a special workshop on quality in simultaneous interpreting which discussed quality from the practitioners' perspective, the research perspective, the didactic perspective as well as the market perspective in an attempt to find out what our clients expect and what will make them happy with the service and product we provide (Shlesinger 1997: 126).

More recently, the Saarbrücken Symposium 2000 was devoted to Translation and 
Interpretation: Models in Quality Assessment. Several speakers emphasized that translation studies ought to determine the expectation profiles of different groups of recipients in order to allow members of the interpreting profession to customize strategies to meet user expectations.

\subsection{Methodology}

\section{Questionnaires}

Questionnaires have been the most common means to determine user expectations and/or responses, as they are the most straightforward scientific way of collecting data on actual quality perception by delegates (Gile 1991: 163-64).

By using questionnaires, the above-mentioned researchers tried to determine respondents' opinions regarding the relative importance of various linguistic and non-linguistic criteria for assessing quality.

This approach is in compliance with translation theories (e.g. Reiss and Vermeer 1984) which emphasize the function and purpose (skopos) of translation: The translator/interpreter needs information about the recipients and their needs and expectations. The orientation of a text towards its receiver is not only important in translation but also in interpretation where the listener is physically present and where the interactions in the conference room give at least indirect feedback to the interpreters, who will be able to adjust to their audience during a meeting (Stenzl 1983: 44).

It should also be borne in mind that user surveys are useful not only for learning about a given situation, but also for conveying messages and provoking questions among respondents, correcting their prejudices or guiding their choices. They may even help us raise awareness of the role of interpreting (Mack and Cattaruzza 1995).

And, finally, it should not be forgotten that empirical research can be used to test theories and possibly become part of theory building.

\section{Other methods}

Of course, questionnaires trying to elucidate users' expectations are but one of the many instruments that bring us closer to determining the relevant quality criteria. Obviously, users' perception of quality of interpretation can never be the only criterion for quality assessment. (Cf. Pöchhacker in this volume.)

Shlesinger (1994) studied the effect of interpretational intonation on comprehension and recall, initiating a line of research that deserves to be further pursued. Pöchhacker (1994) called for quality assessment based on investigating the cognitive end result, i.e. how well the listener had understood the message conveyed. Variables which might be studied in terms of their effect on the end user include speed, pauses, hesitations, intonation patterns, fluency, speech errors, repairs, register and style, cohesion, structure of individual propositions, etc.

\subsection{Description of questionnaire surveys}

In the following, a brief summary of the investigations carried our so far will be presented. It should be pointed out that the empirical studies cited below differ 
widely in terms of method, scope and language combinations. Some of them focus exclusively on user expectations, whereas others evaluate user responses or try to combine both aspects. As a result, there is little comparability among these individual studies.

Bühler (1986)

In her 1986 study that was to trigger research into user expectations Bühler listed fifteen linguistic and extralinguistic criteria and asked AIIC interpreters to rate their relative importance. She concluded that "these criteria reflect the requirements of the user as well as fellow interpreter in a (hopefully) well-balanced mixture" (Bühler 1986: 233).

$\operatorname{Kurz}(1989,1993,1994,1996)$

Bühler's idea to infer user expectations from those of interpreters was put to the test by the author of the present paper (Kurz 1989), who used eight of Bühler's criteria with users.

In an empirical study she tested Bühler's hypothesis that interpreters' quality criteria also reflect user expectations. A bilingual questionnaire (English/German) using a four-point scale was distributed to delegates at a medical conference $(n=47)$ who were asked to rank the first eight criteria in Bühler's questionnaire (native accent, pleasant voice, fluency, logical cohesion, sense consistency, completeness, correct usage of grammar, correct terminology) according to their significance for the quality of interpretation. It was found that some of the criteria that members of the interpreting profession considered highly important, such as native accent, pleasant voice, and correct usage of grammar, were given much lower ratings by the users participating in this study.

Kurz subsequently hypothesized that the results of this first empirical investigation among conference participants, which were obtained in a specific setting, might not apply to all users. To test the hypothesis that different groups of users may have different expectations, comparative studies were undertaken. Surveys using the same questionnaire were conducted at an international conference on quality control ( $\mathrm{n}=$ 29 ) and during a Council of Europe meeting $(n=48)$. The results were compared with those obtained during the medical conference (Kurz 1993, 1994, 1996).

The comparison of three different user groups yielded different evaluation profiles. While there was fairly high agreement by all groups on the importance of some criteria (sense consistency, logical cohesion, correct terminology), conference interpreters and users as well as different user groups among themselves differed in their assessment of the importance of other criteria (correct grammar, pleasant voice, native accent). The demands on the quality of interpretation expressed by the interpreters in Bühler's study were generally higher than those expressed by the delegates.

The findings confirm the validity of the theories that view translation and interpretation as an intercultural communication process and emphasize the importance of situationality and communicative context (Reiss andVermeer 1984). They clearly show that the target-language receiver or listener must be seen as an essential element in the process. 
Gile (1990)

Gile (1990) conducted a medical conference case study. Rather than trying to determine user expectations, he inquired about user responses to the interpretation provided at the meeting. A questionnaire relative to general quality, linguistic output quality, terminological usage, fidelity, quality of voice and delivery (with a scale of five answers) and asking for comments on the main weaknesses of interpretation and for general comments on interpretation was distributed to delegates (18 French, 5 Americans) at a French/English conference on genetic ophthalmology. The results were highly homogeneous. American delegates gave maximum ratings across the board, the French gave somewhat lower scores. Delivery was considered inferior to the other quality components, but this assessment did not influence the assessment of the general quality, which made Gile (1990: 68) assume that "il est possible de formuler l'hypothèse selon laquelle les scientifiques (et techniciens) seraient moins sensibles à la qualité de la voix, du rythme et de l'intonation de l'interprétation que d'autres publics, pour qui elle a peut-être une plus grande importance."

\section{Meak (1990)}

Meak (1990) used a questionnaire comprising nine questions to determine the expectations of ten medical doctors (from different subsdisciplines) with experience at international conferences, although not in a conference setting. Her questions also referred to potential irritants, such as the misuse of technical terms. She concluded that "presque tous le médecins ont montré une certaine indulgence à l'égard de l'interprète qui ne connaît pas exactemment tous les termes techniques, se révélant plus exigeants quant à ses connaissances globales du sujet traité” (Meak 1990: 13).

\section{$\mathrm{Ng}(1992)$}

$\mathrm{Ng}$ (1994) studied end users' reactions to the performance of student interpreters. The study involved ten native Japanese speakers who are likely to use interpreting services and reports on their subjective reactions to prerecorded students' EnglishJapanese interpretations.

Respondents commented on the following subcategories: naturalness (intonation, pronunciation, accent); grammatical structure; choice of vocabulary; and speech levels.

They considered ease of understanding most important. Gender differences were observed: Females tended to place more importance on the correctness of grammatical structures and speech levels, while males tended to confine their comments to the interpreters' lexical choice and overall fluency.

All subjects were concerned with whether interpreters had grasped the meaning of the message. Interestingly, they never once attributed opaqueness in the message to the speaker. Instead, the interpreters were criticized for giving obscure interpretations (Ng 1992: 37). Somewhat different findings were obtained by Moser (1995, 1996). (See below.)

All respondents commented on the interpreters' intonation pattern. They reacted negatively to the overuse of fillers or filled pauses (umms, aahs). $90 \%$ agreed that the appropriate use of speech levels is highly significant in conference interpretation as 
well as business interpretation. However, most of them agreed that it probably is not as important in community interpreting.

Marrone (1993)

Marrone's case study (1993) aimed at elucidating users' expectations and responses. 87 people attending a lecture with consecutive interpretation from German into Italian answered a questionnaire combining questions on the relative importance of a number of quality parameters with others inquiring about such miscellaneous issues as the audience's preferences and reactions with respect to the length of "takes," the speed of delivery, etc. Respondents were asked to rate the importance of three quality parameters: a. completeness of information, b. quality of style and correct terminological usage, and c. quality of intonation and delivery, and of three shortcomings: a. inaccurate terminological usage, b. unpleasant delivery, and c. reproducing the speaker's faults (verbosity, repetitiveness). Marrone found that users seem to attach far more importance to substance, fidelity and completeness of information than to the linguistic quality or the prosodic features of interpretation (good voice, pleasant delivery). Respondents' replies also indicated that it is appropriate for the interpreter to act as a cultural mediator.

\section{Vuorikoski (1993, 1998)}

Vuorikoski (1993) used a questionnaire to study the reception of simultaneous interpretation from English into Finnish in five different seminars (173 respondents). After each seminar a number of participants were also interviewed by phone. The expectation was that the analysis of these seminars might yield some information about the reception of interpretation that would be specific to the Finnish conference culture. The questionnaire was distributed to the participants at the beginning of the seminars and included statements relating to attitudes towards and the evaluation of interpretation. A questionnaire regarding the order of importance of a number of criteria from the viewpoint of the listeners yielded the following ranking order: 1. informed, 2. coherent, or easy to follow, 3. fluent, 4. accurate, 5. correct terminology, 6. pleasant speech rhythm.

Vuorikoski's 1998 report describes the same study about the usefulness and quality of interpretation services in five seminars where simultaneous interpretation was provided. She points out that it cannot be assumed that individual audiences are homogeneous. Consequently, the needs and expectations of individuals vary considerably. Users' expectations are not necessarily meeting- or group-specific (Vuorikoski 1998: 189). Her study also showed that users' simultaneous interpretation needs did not remain constant throughout the meeting but varied. Criticism of the simultaneous interpretation in a given seminar frequently referred to features in the communication situation that were beyond the interpreters' control. Many of these features were linked with the source language address. Vuorikoski's results indicate that collaboration is needed between all the parties involved (organizers, primary addressors, addressees, interpreters) to reach a mutually satisfactory communication situation. 


\section{Kopczynski (1994)}

Kopczynski (1994) conducted a survey among Polish users of interpreting services to determine their attitudes and expectations. The questionnaire was not administered to delegates at a conference but to persons who attended international conferences or participated in negotiations. Three different professional groups were addressed: 20 persons from the humanities, 23 from science and technology, and 14 diplomats. A distinction was made beteween speakers and listeners. The questionnaire also tried to determine whether respondents felt the interpreter should be the speaker's ghost or whether he should intrude, i.e., omit, summarize or add portions of text.

All groups considered content more important than form, citing detailed content and terminological precision as their two top priorities. Form came in the third place: for speakers the most important factor was fluency and for listeners style and fluency.

Both speakers and listeners considered wrong terminology the most important irritant, but differed with regard to the second and third most irritating aspects. Speakers were sensitive to the exact rendition of the content of their speech, while listeners were sensitive to unfinished sentences and grammaticality. All respondents preferred the ghost role of the interpreter but favored some intruder operations.

\section{Mack and Cattaruzza (1995)}

Mack and Cattaruzza (1995) analyzed a sample of five meetings in order to define a profile of specific simultaneous interpretation users, their communication needs, their judgement on, expectations about and attitude towards simultaneous interpretation. Their opinions on "correct terminology" were compared with the findings of other studies.

58 questionnaires were completed by a homogeneous sample of Italian participants with high communiction needs. The authors used Vuorikoski's method (questionnaire, partly checked by telephone and personal interviews). Respondents were asked to evaluate the simultaneous interpretation heard (their factual experience) and to indicate the importance of the criteria given to simultaneous interpretation (their wishes and expectations). It was found that the 'ideal' performance should, above all, be terminologically correct and informed, accurate and easy to follow. Pleasant speech rhythm and fluency were considered less important. Experienced users expected more, particularly with regard to the criteria 'informed' and 'correct terminology'.

\section{Moser (1995, 1996)}

Like a number of previous studies, Moser's survey set out to investigate the hypothesis that different user groups would have different expectations of interpretation and tried to answer such questions as: What constitutes good interpretation from the users' point of view? How do users rank the importance of various quality criteria in interpretation? Do users' expectations vary markedly depending on the type of conference or do users have a basic set of expectations that prevails regardless of the conference type?

94 AIIC interpreters conducted a total of 201 standardized interviews (using a questionnaire with open-ended questions and specific questions) at 84 different 
meetings. The interviewees included speakers and listeners. The conferences were grouped into four categories: large technical meetings, small technical meetings, large general meetings, small general meetings.

Faithfulness to the original is the expectation that most frequently arose spontaneously. Spontaneous references to content, synchronicity, rhetorical skills and the quality of the interpreter's voice were less common.

Differences were found between experienced and unexperienced users. Experienced users ranked content match well ahead of the other factors. There was a preference for focus on essentials over completeness of rendition across almost all conference types. The only group that placed more emphasis on completeness was the age group below 30 . Terminological accuracy was considered more important in technical meetings than in general meetings, and was ranked higher by women than by men.

There was a marked preference for faithfulness to meaning, which was considered more important than literal reproduction. As in the case of the "focus on essentials" criterion, the importance attached to faithfulness to meaning increased with respondents' age.

Synchronicity was one of the interviewees' main expectations. Long pauses and lagging behind the original were considered irritating. Great importance was also attached to clarity of expression and sentence completion. Women found 'umms' and 'aahs' or filling of pauses more irritating than men. A lively, animated voice was considered important, whereas monotonous delivery was found to be irritating. Accent was rated fairly unimportant.

The survey also tried to establish whether participants have very different expectations when attending meetings of a different type. It was found that the importance attached to the main criteria largely remains constant. Clarity of expression, completeness and terminology remain the same in the large majority of cases. Likewise, respondents maintained preference for faithfulness to meaning over literal production. The less technical a conference, the weaker the requirement for completeness. The larger the conference, the greater the preference for interpreters to concentrate on essentials.

Moser's questionnaire is by far the most elaborate. This is not only due to his being able to draw on earlier studies but also to the fact that his is the only survey that had the advantage of being funded by AIIC. Interviews were conducted at 84 meetings, providing us with a broad base of observational data. With a total number of 201 interviews, however, the number of respondents in the various categories of meetings (large and small technical meetings, large and small general meetings) was not much bigger than in some of the previous studies. Therefore, we still need to be careful about making generalizations.

\section{Collados Aís (1998)}

Collados Aís carried out a controlled laboratory study comparing the assessment of interpretations with monotonous intonation versus interpretations with "melodious" intonation. Total sense consistency was present in some cases, while in others intentional inconsistencies were introduced. Interpretations with melodious delivery and mistakes were generally rated better than interpretations with a monotonous delivery and total sense consistency. 
Andres (2000)

As part of her $\mathrm{PhD}$ thesis, Andres (2000) carried out an empirical study on evaluation criteria for consecutive interpretation among potential users $(n=49)$. Gender differences and users' age and experience with consecutive interpretation were taken into consideration.

Completeness, correct terminology and clarity were considered as important or very important by $96 \% .75 \%$ were in favor of focusing on essentials. Register, rhythm and intonation, rhetorical skills, voice and gestures were considered less important. $67 \%$ of the respondents felt that identification with the speaker is important. Nervousness on the part of the interpreter and incomplete sentences were considered irritants. Self-corrections, accent and grammatical errors were found to be less irritating. $84 \%$ of the respondents felt that the interpreter should not correct the speaker or embellish his speech, but $69 \%$ indicated that the interpreter should filter out nuances of the speech.

\subsection{Problems and challenges}

\section{Lack of comparability}

The brief overview of user studies given above shows that, even though fairly extensive observational data have been amassed, there is little comparability among the individual surveys. Several authors (Viezzi 1993, Kalina 1994, Pöchhacker 1994, Moser-Mercer 1996) have pointed out the methodological difficulties involved in quality assessment studies. Others (Mack and Cattaruzza 1995) have called for better coordination or harmonization in the implementation of surveys in order to obtain more reliable and valuable information on users' expectations and perception of simultaneous interpretation. Marrone (1993) suggested the development of a standard questionnaire applicable to most or all interpreting situations, with the possibility of adding specific questions relevant to individual cases.

\section{Users as judges of quality?}

It has frequently been argued that listeners are poor judges of quality since they lack one of the most crucial means of assessing quality - an understanding of the source message. As a rule, the user cannot compare the interpretation with the original and is thus unable to judge whether there is sense consistency ( $\mathrm{Ng} 1992: 38)$. (It should be noted, however, that this does not necessarily apply to all audiences: Vuorikoski (1993: 324) found that Finnish delegates very often understand English and use interpretation "as a kind of support," much in the way as TV subtitles (cf. 3.2).

Shlesinger (1997: 127) points out that smooth delivery may create the false impression of high quality when much of the message may in fact be distorted or even missing. On the other hand, listeners may misjudge a faithful rendering as flawed when in fact it is the source text that accounts for its shortcomings. This was confirmed by Moser $(1995,1996)$ and $\mathrm{Ng}$ (1992), who found that some users tend to blame the interpreter rather than the speaker for lack of clarity (cf. 3.2).

According to Gile (1991), users are not reliable judges of fidelity: Delegates listening to simultaneous interpretation can assess the packaging but may find it difficult to assess fidelity. Besides, they may not be equally interested in all the information 
offered but may focus on particular pieces of information and disregard the rest. In this case, the perception of quality will largely depend on one or several segments that are scrutinized carefully, while the rest of the target-language discourse is hardly attended to. Conference participants may listen to only part of the conference, both because they feel that many segments are not relevant or interesting and because the required degree of concentration is very high. Their assessment of segments they are not interested in will tend to be biased towards the packaging rather than the content, which may lead to a sursprisingly favorable assessment of quality in conferences in which the interpreters themselves feel that they have done a poor job (Gile 1991: 198).

In view of all these difficulties, Pöchhacker (1994) rightly emphasizes an important component of quality assurance-the inspection of the actual product-and suggests a multi-parameter model for description and analysis. However, he admits that even if such a method were achieved, our analytical study of the products would have to be complemented with the delegates' (subjective) assessment of the texts under study. "Direct delegate response is indispensable if we want to establish the thresholds at which a particular constellation and quantity of quality-related features in the material text reaches 'critical mass' and leads to 'bad marks' for the interpreting services" (Pöchhacker 1994: 241).

Shlesinger (1997) states that quality is an elusive concept. Quality according to what criteria? Quality for whom? She goes on to ask, "Do our clients know what's good for them?" (Shlesinger 1997: 126).

I would like to argue that even though our clients may not always know what is good for them, we cannot prevent them from having expectations. As service providers interested in client satisfaction, conference interpreters should try to meet their clients' expectations to the best of their ability. Whenever these expectations or demands are unreasonable, members of the profession and professional organizations should convincingly show why they cannot be met. In trying to prove my point, I will take an interdisciplinary approach. In the following I will briefly refer to some of the basic tenets of marketing and show how they apply to the interpreting profession.

\section{USER SATISFACTION AS A MEASURE OF QUALITY}

According to marketing experts, customer satisfaction with a purchase depends upon the product's/service's performance relative to a buyer's expectations. A customer may experience various degrees of satisfaction. If the product's/service's performance falls short of expectations, the customer is dissatisfied. If performance matches expectations, the customer is satisfied. If performance exceeds expectations, the customer is highly satisfied or delighted. (Kotler and Armstrong 1994: 553)

The European Organization for Quality Control defines quality as "the totality of features and characteristics of a product or service that bear on its ability to satisfy a given need" (Wenger 1981). This is clearly a customer-centered definition of quality. It suggests that a company/service provider has delivered quality whenever its/his product/service meet or exceed customer needs, requirements, and expectations. A company/service provider that satisfies most of its/his customers' needs most of the time is a quality company/service provider. 
“The key is to exceed the customers' service-quality expectations. [...] The service provider needs to identify the expectations of target customers concerning service quality" (Kotler and Armstrong 1994: 646).

If we accept the above definition, we can say:

Quality of service (customer satisfaction) = service quality delivered - service expected

The formula could also read:

Quality = Actual Service - Expected Service

Quality is evaluated by customers in terms of what they actually receive in relation to what they expected. Clearly, the customer defines quality. Consequently, absolute measurements of service quality that do not include customer expectations miss the point (Heskett, Sasser and Hart 1990: 6).

Knowledge of user expectation profiles, therefore, is extremely valuable, and it is in our interest to determine the particular characteristics of groups most likely to constitute our target market(s). Because needs and expectations vary by customer and situation, service quality is a highly subjective matter.

Thus, it should not come as a surprise that studies of user expectations point to variability in the quality expectations of different user groups as well as to discrepancies in the attitudes of participants in the role of listener (target-text receiver) and speaker (source-text producer). (Cf. Pöchhacker in this volume.)

Customers have different expectations of the quality they can expect from different types of service providers, competitors within the same industry, and the same providers at different points in time and under varying conditions.

The question raised by Pöchhacker (in this volume) - whether a medical doctor and researcher would have the same quality criteria and expectations for interpreters and interpreting at a medical congress and in interviews with patients who speak a different language - would, therefore, probably receive a negative answer. (In Ng's study, e. g. respondents indicated that the appropriate use of speech levels is highly significant in conference and business interpretation but less important in community interpreting.)

Since the value of a service to a customer is determined by service quality and price, price considerations also come into the assessment. Low-priced and highpriced interpretation services are often assessed differently (Gile 1991, Feldweg 1996).

\section{Conference Interpreters - High-Quality Service Providers?}

As outlined at the beginning of this paper, the International Association of Conference Interpreters considers quality of service one of its priorities. What about the individual members of this professional organization? Are they aware of what the users of their services expect so that they can provide quality (defined as user satisfaction)?

A tentative answer can be obtained by comparing conference interpreters' quality-criteria assessment (Bühler 1986) with that given by conference participants (Kurz 1989, 1993, 1994, 1996). 
Table 1 shows the significance attributed to eight quality criteria for interpretation by the AIIC interpreters $(\mathrm{n}=47)$ in Bühler's study and by the delegates $(\mathrm{n}=$ 124) in Kurz's surveys.

TABLE 1

Assessment of quality criteria for simultaneous interpretation by conference interpreters and delegates

\begin{tabular}{|l|cc|c|}
\hline Criterion & \multicolumn{2}{|c|}{$\begin{array}{c}\text { Interpreters } \\
(\mathrm{n}=47)\end{array}$} & $\begin{array}{c}\text { Delegates } \\
(\mathrm{n}=124)\end{array}$ \\
\hline Accent & 2.9 & \multicolumn{2}{|c|}{2.365} \\
\hline Voice & \multicolumn{2}{|c|}{3.085} & 2.6 \\
\hline Fluency & \multicolumn{2}{|c|}{3.486} & 3.1 \\
\hline Logical cohesion & 3.8 & \multicolumn{2}{|c|}{3.458} \\
\hline Sense consistency & \multicolumn{2}{|c|}{3.957} & 3.69 \\
\hline Completeness & \multicolumn{2}{|c|}{3.426} & 3.2 \\
\hline Grammar & 3.38 & 2.6 \\
\hline Terminology & \multicolumn{2}{|c|}{3.489} & 3.4 \\
\hline
\end{tabular}

As can be seen, interpreters' ratings were consistently higher than those obtained from delegates, suggesting that AIIC interpreters tend to place greater demands on their own performance.

Figure 1 shows that a. interpreters gave consistently higher rankings, and $\mathrm{b}$. their ranking of the first six criteria (accent, voice, fluency, logical cohesion, sense consistency, completeness) was virtually parallel to that given by delegates, which means that they attributed very similar relative weights to these performance criteria. Differences were obtained for the last two criteria. Interpreters considered 'grammar' far more important than delegates did, while only slightly surpassing delegates' assessment of the significance of 'terminology'.

FIGURE 1

Significance of quality criteria as seen by conference interpreters and delegates
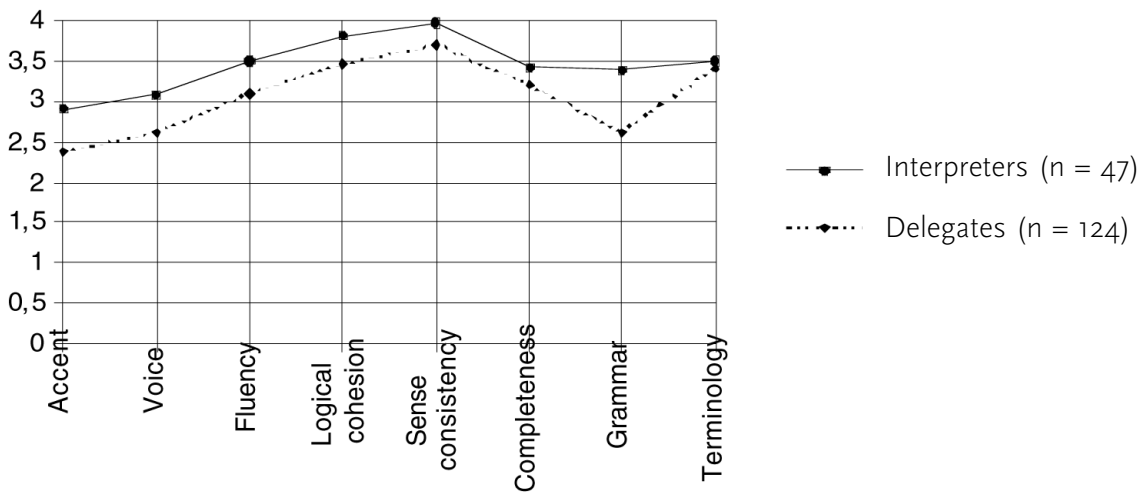
Obviously, these findings cannot be interpreted as demonstrating that, owing to their high self-imposed quality standards, conference interpreters succeed in consistently surpassing their users' expectations, thus leaving them highly satisfied. The only conclusions that can be drawn with any certainty are that

a. if the interpreters participating in Bühler's study had been working for the delegates at one of the three conferences studied by Kurz, and

b. if on that occasion they had actually managed to live up to the standards they had set for themselves,

their listeners would indeed have found that their expectations regarding criteria 1 through 8 were exceeded and would consequently have been highly satisfied in this regard.

\section{CONCLUSION}

For the purpose of this paper quality has been defined as user satisfaction. As satisfying our users implies meeting their service-quality expectations, empirical studies designed to provide us with knowledge of user expectation profiles are a line of research worth pursuing. They should provide us with information that will prove beneficial to both the exercise and the teaching of the profession. Even though the present paper focused exclusively on conference interpreting, user expectation surveys have their place in the assessment of quality across the board - from conference interpreting to community interpreting.

The usefulness of feedback from our listeners is illustrated by a comment by Lord Simon of Highbury, Minister for Trade and Competitiveness in Europe, on the occasion of the official opening of the exhibition Interpreting in the new millennium: "With experience you learn to tell the difference between quite good, very good and excellent interpreters." (Gebhard 1999).

\section{REFERENCES}

Andres, D. (2000): Konsekutivdolmetschen und Notizen. Empirische Untersuchung mentaler Prozesse bei Anfängern in der Dolmetscherausbildung und professionellen Dolmetschern, thesis, University of Vienna.

BüHLER, H. (1986): "Linguistic (semantic) and extra-linguistic (pragmatic) criteria for the evaluation of conference interpretation and interpreters," Multilingua, 5-4, pp. 231-235.

Chernov, G. (1985): “Interpretation Research in the Soviet Union: Results and Prospects," Translators and their Position in Society. Proceedings of the Xth World Congress of FIT (H. Bühler, ed.), Vienna, Braumüller, pp. 169-177.

Collados Ais, A. (1998): La evaluación de la calidad en interpretación simultánea. La importancia de la comunicación no verbal, Granada, Editorial Comares.

DéJeAn Le FÉAL, K. (1990): “Some Thoughts on the Evaluation of Simultaneous Interpretation," Interpreting - Yesterday, Today, and Tomorrow (D. and M. Bowen, eds.), Binghamton (NY), SUNY, pp. 154-160.

Feldweg, E. (1996): Der Konferenzdolmetscher im internationalen Kommunikationsprozeß, Heidelberg, Julius Groos.

Gebhard, S. (1999): “Learning to tell the difference," AIIC Bulletin, XXVII/2, p. 7.

Gerver, D. (1972): Simultaneous Interpretation and Human Information Processing, London, Social Science Report, HR 566/1. 
GiLe, D. (1989): La communication linguistique en réunion multilingue. Les difficultés de la transmission informationnelle en interprétation simultanée, thèse, Université Paris III.

— (1990): "L'évaluation de la qualité de l'interprétation par les délégués: une étude de cas," The Interpreters' Newsletter, 3, pp. 66-71.

- (1991): "A Communication-Oriented Analysis of Quality," Translation: Theory and Practice. ATA Scholarly Monograph Series (M. L. Larson, ed.), Binghamton (NY), SUNY, vol. 5, pp. 188-200.

Gold, D. L. (1973): “On Quality in Interpretation,” Babel 19-4, pp. 154-155.

Heskett, J. L., W. E. Sasser and C. W. L. Hart (1990): Service Breakthroughs. Changing the Rules of the Game, New York, Free Press.

Kahane, E. (2000): “Thoughts on the Quality of Interpretation,” < http://www.aiic.net.ViewPage. $\mathrm{cfm} /$ page197.htm $>$.

KopCZYNSKI, A. (1994): "Quality in Conference Interpreting: Some Pragmatic Problems," Translation Studies. An interdiscipline (M. Snell-Hornby, F. Pöchhacker and K. Kaindl, eds.), Amsterdamand Philadelphia, John Benjamins, pp. 189-198.

- (1994): "Quality in conference interpreting: Some pragmatic problems," in S. LAMBERT and B. Moser-Mercer (eds.), Bridging the Gap: Empirical research in simultaneous interpretation (pp. 87-99), Amsterdam and Philadelphia, John Benjamins.

Kotler, P. and G. Armstrong (1994): Principles of Marketing, $6^{\text {th }}$ ed., Englewood Cliffs (NJ), Prentice-Hall.

Kurz, I. (1989): "Conference Interpreting-User Expectations," Coming of Age. Proceedings of the 30th Annual Conference of the American Translators Association (D. L. Hammond, ed.), Medford (NJ), Learned Information, pp. 143-148.

- (1993): “Conference Interpretation: Expectations of Different User Groups," The Interpreters' Newsletter, 5, pp. 13-21.

— (1994): "What Do Different User Groups Expect from a Conference Interpreter?," The Jerome Quarterly, 9-2, pp. 3-7.

— (1996): Simultandolmetschen als Gegenstand der interdisziplinären Forschung, Vienna, WUVUniversitätsverlag.

Mack, G. and L. Cattaruzza (1995): "User Surveys in Simultaneous Interpretation: A Means of Learning about Quality and/or Raising some Reasonable Doubts," Topics in Interpreting Research (J. Tommola, ed.), Turku, University of Turku, pp. 51-68.

Mackintosh, J. (1994): “User expectation survey. Interim report,” AIIC Bulletin, XXII/2, pp. 13-17. Marrone, S. (1993): “Quality: A Shared Objective," The Interpreters' Newsletter, 5, pp. 35-41.

MeAK, L. (1990): «Interprétation simultanée et congrès médical: attentes et commentaires», The Interpreters' Newsletter 3, p. 8-13.

Moser, P. (1995): Simultanes Konferenzdolmetschen. Anforderungen und Erwartungen der Benutzer. Endbericht im Auftrag von AIIC, Vienna, SRZ Stadt und Regionalforschung GmbH.

- (1996): "Expectations of Users of Conference Interpretation," Interpreting 1/2, pp. 145-178.

Moser-Mercer, B. (1996): "Quality in interpreting: Some methodological issues," The Interpreters' Newsletter 7, pp. 43-55.

NG, B. C. (1992): “End Users' Subjective Reaction to the Performance of Student Interpreters," The Interpreters' Newsletter, Special Issue 1, pp. 35-41.

Pöchнacker, F. (1994): "Quality Assurance in Simultaneous Interpreting," in C. Dollerup and A. Lindegaard (eds.), Teaching Translation and Interpreting 2: Insights, Aims and Visions (pp. 233-242), Amsterdam and Philadelphia, John Benjamins.

Reiss, K. and H. Vermeer (1994): Grundlegung einer allgemeinen Translationstheorie, Tübingen, Niemeyer.

Selesкovitch, D. (1986): “Who Should Assess an Interpreter’s Performance?” Multilingua, 5-4, p. 236.

Shlesinger, M. (1994): "Intonation in the Production and Perception of Simultaneous Interpretation," Bridging the Gap: Empirical research in simultaneous interpretation (S. Lambert and B. Moser-Mercer, eds), pp. 225-236), Amsterdam and Philadelphia, John Benjamins. 
SHLESINGER, M. (1997): “Quality in Simultaneous Interpreting," Conference Interpreting: Currrent Trends in Research (Y. Gambier, D. Gile and C. Taylor, eds), Amsterdam and Philadelphia, John Benjamins, pp. 123-131.

Stenzl, C. (1983): Simultaneous Interpretation. Groundwork towards a Comprehensive Model, dissertation, University of London.

Thiery, C. (1990): “The Sense of Situation in Conference Interpreting," Interpreting-Yesterday, Today, and Tomorrow (D. and M. Bowen, eds), pp. 183-188), Binghamton NY, SUNY.

VIEZZI, M. (1993): “Considerations on Interpretation Quality Assessment," Translation—the Vital Link. Proceedings of the XIIIth FIT World Congress (C. Picken, ed.), London, Institute of Translation and Interpreting, vol. 1, pp. 389-397.

Vuorikoski, A.-R. (1993): "Simultaneous interpretation-User experience and expectation," in C. Picken (ed.), Translation-the vital link. Proceedings of the XIIIth World Congress of FIT (vol. 1, pp.317-327), London, Institute of Translation and Interpreting.

- (1998): "User Responses to Simultaneous Interpreting," Unity in Diversity? Current Trends in Translation Studies (L. Bowker, M. Cronin, D. Kenny and J. Pearson, eds.), Manchester, St. Jerome Publishing, pp. 184-197.

Wenger, L., ed. (1981): Glossary of Terms Used in the Management of Quality, 5th ed., Bern, EOQC Secretariat. 